\title{
HUBUNGAN ADOPSI IFRS PSAK NO.16 (REVISI 2007) DENGAN DISCRETIONARY ACCRUALS SEBAGAI ALAT MANAJEMEN LABA SERTA PENGARUHNYA TERHADAP NILAI PERUSAHAAN
}

\author{
Andison \\ Mahasiswa Magister Akuntansi \\ Universitas Mercubuana, Jakarta \\ dikaandi36@yahoo.co.id
}

Received: $15-02-17$

Reviewed: $27-02-17$

Accepted: $13-04-17$

Published: 20-07-17
ABSTRAK

The purpose of this study to determine the effect of earnings management on firm performance. Earnings management proxy by discretionary accruals, firm performance meausured by Tobins's Q. The study used secondary data listed in Indonesia Stock Exchange on manufacturing company period 2013 - 2015 and result sampel 33 firm-years. Data analysis with regression. The result show earnings management negative effect on firm performance, and supported Huang et. al. (2009).

Keywords: earning management, firm performance, SFAS No.16

\section{PENDAHULUAN}

Standar akuntansi keuangan merupakan pedoman untuk menyusun laporan keuangan perusahaan. Dalam beberapa tahun terakhir, terdapat kecenderungan pada dunia bisnis global untuk menggunakan International Financial Reporting Standards (IFRS). IFRS merupakan standar pelaporan keuangan yang dibuat oleh Dewan Standar Akuntansi Internasional (IASB). IASB merupakan lembaga independen yang didanai oleh pihak swasta dan berperan dalam menyusun standar akuntansi berbasis di London (Norton, et al., 2006). Norton, et al. (2006), menerangkan bahwa tujuan dari IASB adalah mengembangkan standar akuntansi internasional yang berkualitas tinggi, dapat dipahami, dan dapat dilaksanakan secara global untuk menghasilkan laporan keuangan yang transparan dan dapat diperbandingkan.

Standar akuntansi yang berlaku di Indonesia sebelum adopsi IFRS dilakukan merupakan standar yang fleksibel yang memungkinkan adanya pemberlakuan metodemetode akuntansi yang berbeda pada setiap perusahaan. Standar yang fleksibel ini menimbulkan kemungkinan terjadinya accounting creative dan manajemen laba. Pengaruh adopsi IFRS pada manajemen perusahaan yaitu persyaratan akan item-item pengungkapan semakin tinggi, dengan mengadopsi IFRS manajemen memiliki akuntabilitas yang tinggi dalam menjalankan perusahaan, laporan keuangan perusahaan dapat digunakan untuk pengambilan keputusan bagi pihak di luar manajemen karena informasi yang terdapat 
dalam laporan keuangan tersebut menjadi lebih relevan, krusial, akurat dan mudah untuk dipahami. Dengan mengadopsi IFRS, akan lebih membantu para investor dalam mengestimasikan investasi pada perusahaan berdasarkan data-data laporan keuangan perusahaan pada tahun sebelumnya, semakin meningkatnya tingkat pengungkapan suatu perusahaan maka berdampak pada rendahnya biaya modal perusahaan.

Informasi dalam laporan keuangan harus relevan dan representasi agar dapat mempengaruhi tujuan pengambilan keputusan. Informasi yang diberikan manajemen kepada pemegang saham harus dapat mewakili kondisi baik buruknya kondisi ekonomi suatu perusahaan. Scott (2012) menyatakan bahwa apabila beberapa pihak yang terkait dalam transaksi bisnis memiliki informasi lebih dibandingkan pihak lainnya, maka kondisi tersebut dikatakan sebagai asimetri informasi (information asymmetry). Kondisi asimetri tersebut dimanfaatkan oleh pihak manajemen untuk memaksimalkan kepentingan pribadinya dengan menyembunyikan informasi-informasi yang tidak diketahui oleh pemegang saham. Semuanya tidak terlepas dari apa yang disebut sebagai usaha-usaha untuk mendapatkan keuntungan atau manfaat pribadi (obtaining private gains). Pihak manajemen dapat mempengaruhi angka-angka akuntansi dalam pelaporan keuangan dengan cara melakukan manajemen laba.
Manajemen laba diduga dilakukan oleh pihak manajemen dalam proses pelaporan keuangan suatu perusahaan karena mereka mengharapkan suatu manfaat dari tindakan yang dilakukan. Manajemen laba tidak harus dikaitkan dengan upaya untuk memanipulasi data atau informasi akuntansi, tetapi lebih dikaitkan dengan pemilihan metode akuntansi (accounting methods) untuk mengatur keuntungan yang bisa dilakukan karena memang diperkenankan menurut accounting regulations. Siregar dan Bachtiar (2003) perusahaan yang melakukan manajemen laba cenderung mengungkapkan informasi lebih sedikit dalam laporan keuangannya agar tidak terdeteksi. Perusahaan dengan tingkat pengungkapan minimal cenderung melakukan manajemen laba dan sebaliknya.

Sulistyanto (2008) mengemukakan bahwa keberadaan aturan dalam standar akuntansi dapat merupakan salah satu alat yang mengakomodasi dan memfasilitasi perusahaan melakukan kecurangan. Perusahaan dapat menyembunyikan kecurangan dengan memanfaatkan berbagai metode dan prosedur yang terdapat dalam standar akuntansi, sehingga standar akuntansi seolah-olah mengakomodasi dan memberi kesempatan perusahaan untuk mengatur dan mengelola laba perusahaan. Upaya mengurangi manajemen laba yaitu dengan melakukan koreksi terhadap standar akuntansi. Perbaikan standar akuntansi yang saat ini sedang menjadi isu adalah adopsi International Financial 
Reporting Standard (IFRS). Cai et al. (2008) mengungkapkan salah satu isu dari IASB adalah bahwa IFRS bertujuan untuk menyederhanakan berbagai alternatif kebijakan akuntansi yang diperbolehkan dan diharapkan dapat membatasi pertimbangan kebijakan manajemen (management's discretion) terhadap manipulasi laba sehingga dapat meningkatkan kualitas laba. Tingkat manajemen laba dalam sebuah laporan keuangan perusahaan dapat dilihat dengan cara menghitung (Discretionary Accruals) atau kebijakan akrual yang muncul karena kebijakan manajemen.

Konvergensi IFRS di Indonesia sudah dimulai pada tahun 2008 yang ditandai dengan terdapatnya perubahan-perubahan dalam PSAK sebagai akibat diadopsinya IFRS. Tujuan konvergensi ini adalah untuk mengeliminasi perbedaan (gap) antara standar akuntansi di Indonesia dengan IFRS (Wondabio, 2011). Dampak dari konvergensi IFRS adalah menghasilkan laporan keuangan yang lebih relevance dan faithful representation karena lebih banyak menggunakan nilai wajar (fair value). Secara garis besar IFRS mengatur pembuatan dan penyusunan laporan keuangan yang penilaian aset perusahaan harus berdasarkan pada nilai wajar (Laili, 2008). Salah satu penggunaan nilai wajar yang diadopsi di PSAK hasil dari konvergensi IFRS adalah PSAK No.16 (revisi 2007) tentang revaluasi aktiva tetap, salah satunya adalah perbedaan pengukuran aset tetap setelah pengakuan awal.
Pada PSAK 16 (Revisi 1994), aset tetap disajikan berdasarkan nilai perolehan aktiva tersebut dikurangi akumulasi penyusutan. PSAK 16 (Revisi 1994) tidak memperkenankan revaluasi aktiva tetap (SAK, 2002). Sedangkan pengukuran setelah pengakuan menurut PSAK No. 16 (SAK, 2012); "Entitas memilih antara model biaya atau model revaluasi sebagai kebijakan akuntansinya dan menerapkan kebijakan tersebut terhadap seluruh aset tetap dalam kelompok yang sama. Pada model biaya, setelah pengakuan sebagai aset, aset tetap dicatat pada biaya perolehan dikurangi akumulasi penyusutan dan akumulasi rugi penurunan nilai aset. Sedangkan untuk model revaluasi setelah pengakuan sebagai aset, aset tetap yang nilai wajarnya dapat diukur secara andal harus dicatat pada jumlah revaluasian, yaitu nilai wajar pada tanggal revaluasi dikurangi akumulasi penyusutan dan akumulasi rugi penurunan nilai setelah tanggal revaluasi. Revaluasi dilakukan dengan keteraturan yang cukup reguler untuk memastikan bahwa jumlah tercatat tidak berbeda secara material dengan jumlah yang ditentukan dengan menggunakan nilai wajar pada akhir periode pelaporan."

Brown et al, (1992);. Whittred dan Chan, (1992) dan $\mathrm{Hu}$, et al (2015), pilihan akuntansi untuk melakukan revaluasi aktiva tetap dikaitkan dengan prilaku opportunistik manajerial sehubungan dengan contracting, kebutuhan keuangan dan political costs. Penelitian Brown et al. (1992), Whittred dan Chan (1992), Cotter 
dan Zimmer (1995), dan Christensen dan

Nikolaev (2013) di Autralia membuktikan

bahwa perusahaan yang mememiliki tingkat leverage yang tinggi mempengaruhi kebijakan perusahaan untuk melakukan revaluasi aktiva tetap. Easton et al. (1993) dalam penelitiannya, dimana $40 \%$ dari responden secara ekplisit mengungkapan bahwa revaluasi aktiva tetap bertujuan untuk mengurangi hutang perusahaan dan melonggarkan kendala hutang. Hasil temuannya mengindikasikan bahwa revaluasi aktiva tetap berkaitan dengan peningkatan keuangan perusahaan yang terkait dengan contracting. Disisi lain, revaluasi aktiva tetap dengan penggunaan nilai wajar dapat meningkatkan kualitas laporan keuangan yang dapat mengurangi asimetri informasi antara manajer dan pemegang saham. Danbolt dan Ress (2008) membuktikan bahwa kandungan informasi revaluasi aktiva tetap berpengaruh positif terhadap reaksi pasar.

Berdasarkan teori signaling bahwa laba dapat memberikan sinyal yang positif mengenai prospek perusahaan di masa depan perusahaan. Dengan adanya pertumbuhan laba yang terus meningkat dari tahun ke tahun, akan memberikan sinyal yang positif mengenai kinerja perusahaan. Selain itu peningkatan laba akan berdampak pada value of the firm (nilai perusahaan) yang akan tercermin pada nilai saham. Jadi dengan demikian nilai saham merupakan indeks yang tepat untuk mengukur efektivitas perusahaan, sehingga seringkali dikatakan memaksimumkan nilai perusahaan juga berarti memaksimumkan kekayaan pemegang saham. Saham suatu perusahaan bisa dinilai dari pengembalian (return) yang diterima oleh pemegang saham dari perusahaan yang bersangkutan. Return bagi pemegang saham bisa berupa penerimaan dividen tunai ataupun adanya perubahan harga saham pada suatu periode (Ross 2002). Hal ini, yang mendorong perusahaan untuk me-manage atau melaporkan laba sedemikian agar harga saham/investor merespon baik tentang kinerja perusahaan. Dengan demikian, laba menjadi salah satu komponen penting dalam mengambil keputusan serta menjadi pusat perhatian bagi para penggunanya. Huang et al (2009) dalam penelitiannya membuktikan bahwa earning management berpengaruh positif terhadap nilai perusahaan. Zhang et al (2006); Yip dan Nguyen (2011) membuktikan bahwa earning management berpengaruh negatif terhadap nilai perusahaan.

\section{Hipotesis Penelitian}

\section{Teori Agensi}

Teori keagenan menyatakan bahwa antara manajemen dan pemilik mempunyai kepentingan yang berbeda (Jensen dan Meckling, 1976). Perusahaan yang memisahkan fungsi pengelolaan dan kepemilikan akan rentan terhadap konflik keagenan (Lambert, 2001). Dalam model keagenan dirancang sebuah sistem yang melibatkan kedua belah pihak, sehingga 
diperlukan kontrak kerja antara pemilik (principal) dan manajemen (agent). Dalam kesepakatan tersebut diharapkan dapat memaksimumkan utilitas principal, dan dapat memuaskan serta menjamin agen untuk menerima reward dari hasil aktivitas pengelolaan perusahaan. Perbedaan kepentingan antara pemilik dan manajemen terletak pada maksimalisasi manfaat (utility) pemilik (principal) dengan kendala (constraint) manfaat (utility) dan insentif yang akan diterima oleh manajemen (agent). Karena kepentingan yang berbeda sering muncul konflik kepentingan antara pemegang saham/ pemilik (principal) dengan manajemen (agent).

Apabila laba yang dilaporkan oleh perusahaan meningkat maka informasi tersebut dapat dikategorikan sebagai sinyal baik karena mengindikasikan kondisi perusahaan yang baik. Sebaliknya apabila laba yang dilaporkan menurun maka perusahaan berada dalam kondisi tidak baik sehingga dianggap sebagai sinyal yang jelek. Brigham dan Houston (2001) menyatakan bahwa isyarat adalah suatu tindakan yang diambil manajemen perusahaan yang memberi petunjuk bagi investor tentang bagaimana manajemen memandang prospek perusahaan. Perusahaan dengan prospek yang menguntungkan akan mencoba menghindari penjualan saham dan mengusahakan setiap modal yang baru diperlukan dengan cara-cara lain. Sedangkan dengan prospek yang kurang menguntungkan akan cenderung untuk menjual saham.

\section{Teori Akuntansi Positif}

Praktik manajemen laba dikaitkan dengan suatu teori akuntansi, yaitu teori akuntansi positif atau positive accounting theory. Teori akuntansi positif merupakan teori akuntansi yang berusaha mengungkapkan bahwa faktor-faktor ekonomi tertentu atau ciri-ciri suatu unit usaha tertentu bisa dikaitkan dengan perilaku manajer atau para pembuat laporan keuangan. Teori ini dapat memberikan pedoman kepada para pembuat keputusan kebijakan akuntansi dalam melakukan perkiraan-perkiraan atau penjelasan-penjelasan akan konsekuensi dari keputusan tersebut. Manajemen laba dilakukan oleh manajer atau para pembuat laporan keuangan dalam proses pelaporan keuangan suatu organisasi karena mengharapkan suatu manfaat dari tindakan yang dilakukan. Manajemen laba memberikan gambaran akan perilaku manajer dalam melaporkan kegiatan usahanya pada suatu periode tertentu, yaitu adanya kemungkinan munculnya motivasi tertentu yang mendorong mereka untuk mengatur data keuangan yang dilaporkan. Prediksi yang dibuat oleh teori akuntansi positif diorganisasikan secara luas pada tiga hipotesis yang diformulasikan oleh Watts dan Zimmerman (1990) yaitu hipotesis rencana bonus, hipotesis kontrak hutang, dan hipotesis biaya politik. Ketiga hipotesis tersebut menjelaskan hubungan antara kebijakan akuntansi dengan manajemen laba. 
Teori akuntansi positif juga digunakan untuk menjelaskan motivasi melakukan revaluasi aset (Azouzi dan Jarboui, 2012). Hal ini berarti bahwa perusahaan akan mengubah metode akuntansi dari historical cost menjadi fair value diantaranya untuk meminimumkan biaya politik (Watt dan Zimmerman, 1960). Revaluasi aset dapat dijadikan sebagai alat untuk menurunkan biaya politik dan juga dapat digunakan sebagai sinyal adanya pertumbuhan perusahaan (Azouzi dan Jarboui, 2012)

\section{PSAK 16 (Revisi 2007)}

Revaluasi aset tetap adalah penilaian kembali aset tetap. Revaluasi sering dimaknai penilaian ulang yang menyebabkan nilai aset menjadi lebih tinggi, padahal revaluasi dapat menghasilkan nilai yang lebih rendah maupun lebih tinggi dari aset tercatat (Martani, 2012). Alasan yang mendasari keputusan revaluasi aset ini oleh perusahaan adalah untuk memastikan bahwa nilai wajar dari aset tetap perusahaan tercermin dalam laporan keuangan. Revaluasi aset mengacu pada penyajian kembali atas nilai buku aset (carrying amount) sehingga mendekati nilainya sekarang (Brown et al, 1992). Revaluasi aset mempengaruhi laporan keuangan dalam dua cara. Pertama, mengubah jumlah aset yang ditampilkan di laporan posisi keuangan dan angka dalam ekuitas. Kedua, revaluasi mengubah keuntungan saat ini dan masa yang akan datang yang disebabkan oleh perubahan depresiasi dari aset yang direvaluasi (Lin dan
Peasnell, 2000a). Tay (2009), Revaluasi aset tetap dapat berupa upward revaluation dan downward revaluation. Upward revaluation adalah penyajian kembali nilai buku aset sejauh hal tersebut tidak melebihi net current value atau recoverable value. upward revaluation mengacu pada incremental value dari nilai buku aset, sedangkan downward revaluation berarti bahwa net current value dibawah nilai bukunya. Upward revaluation aset tetap meningkatkan nilai ekuitas pemegang saham dan nilai aset tetap.

\section{Manajemen Laba}

Scott (2009), manajemen laba merupakan suatu tindakan manajemen untuk memilih kebijakan akuntansi dari suatu standar tertentu agar mencapai target laba tertentu, dengan tujuan memaksimalkan kesejahteraan pihak manajemen dan atau nilai perusahaan. Ada dua cara pemahaman atas manajemen laba (Scott, 2009). Pertama, manajemen laba sebagai peluang bagi manajer untuk meningkatkan kepentingan pribadinya, atau dikenal dengan Oportunistic Earnings Management. Kedua, manajemen laba dapat dipandang dari perspektif efficient contracting (Efficient Earnings Management) adalah manajemen laba dapat digunakan oleh manajer sebagai jalan keluar untuk melindungi kepentingan perusahaan dalam mengantisipasi kejadian-kejadian tak terduga demi keuntungan pihak-pihak yang terlibat dalam kontrak. 
Schipper (1989), earning management atau manajemen laba diartikan sebagai suatu intervensi dengan maksud tertentu terhadap proses pelaporan keuangan eksternal dengan sengaja memperoleh beberapa keuntungan pribadi. Manajemen laba terjadi ketika para manajer menggunakan judgment dalam pelaporan keuangan dan penyusunan transaksi untuk merubah laporan keuangan yang menyesatkan terhadap pemegang saham atas dasar kinerja ekonomi organisasi atau untuk mempengaruhi hasil sesuai dengan kontrak yang tergantung pada angka-angka akuntansi yang dilaporkan.

\section{Nilai Perusahaan}

Nilai pasar perusahaan merupakan harga saham perusahaan yang terbentuk dari transakasi antara penjual dan pembeli, karena harga pasar saham dianggap sebagai gambaran dari nilai aset perusahaan. Tobin's Q merupakan salah satu alternatif yang digunakan dalam menilai perusahaan yang dikembangkan oleh Profesor James Tobin. Tobin's Q merupakan harga pengganti dari biaya yang dibutuhkan guna memperoleh aset yang sama persis dengan aset yang dimiliki perusahaan. James Tobin (1967) dan (Pradita, 2010), mengungkapkan bahwa rasio ini hampir sama dengan market-to-bookvalue ratio, namun ada beberapa karakteristik berbeda yang dimiliki Tobin's Q. Pertama, Tobin's Q yang menggunakan replacement cost sebagai denominator bukan book value of total equity. Kedua, Tobin's Q menggunakan market value of total asset, karena perusahaan tidak hanya menggunakan ekuitas dalam mendanai kegiatan operasionalnya, namun perusahaan juga menggunakan sumber-sember lain seperti hutang jangka pendek maupun jangka panjang.

\section{Manajemen Laba dan Nilai Perusahaan}

$\mathrm{Hu}$, Percy dan Yao (2015), mengatakan bahwa pilihan akuntansi untuk melakukan revaluasi aktiva tetap dikaitkan dengan prilaku opportunistik manajerial sehubungan dengan praktik manajemen laba. Di sisi lain, revaluasi aset dapat mengurangi masalah keagenan ketika motivasi utama manajer untuk revaluasi aset tetap adalah mengungkapkan nilai wajar aset terhadap pengguna laporan keuangan dan untuk mengurangi asimetri informasi antara manajer dan pemegang saham. Beberapa studi menguji kandungan informasi dari revaluasi aktiva tetap berpengaruh positif terhadap reaksi pasar saham (Ress, 2008; Hu, Percy dan Yao, 2015).

Laba merupakan komponen penting bagi banyak pihak, sehingga manajemen akan berusaha menyajikan laba yang disesuaikan dengan tujuan yang diinginkan oleh manajer, seperti melakukan manajeman laba (earnings management). Earnings management merupakan suatu cara penyajian laba yang disesuaikan dengan tujuan yang diinginkan oleh manajer, melalui pemilihan suatu set kebijakan akuntansi atau melalui pengelolaan akrual (Scott, 2000). Earnings management dapat dilihat dalam dua 
prespektif: pertama, earnings management merupakan prilaku manajemen yang oportunistik yang dikaitkan dengan mekanisme kompensasi, kontrak utang dan biaya politik. Kedua, earnings management merupakan prilaku manajamen yang efisien yang bermanfaat bagi perusahaan, jika dilihat dari prespektif efisiensi kontrak.

Penelitian ini didasarkan pada teori hipotesis pasar efisien (Efficient Market Hypothesis/EMH) mengasumsikan bahwa pasar modal Indonesia termasuk dalam kategori efisien setengah kuat. Dalam bentuk ini, harga saham akan mencerminkan berbagai informasi yang dipublikasikan, termasuk informasi dalam laporan keuangan. Huang et al (2009) dalam penelitiannya membuktikan bahwa earning management berpengaruh positif terhadap nilap perusahaan. Dalam hal ini bahwa tindakan manajemen laba yang dilakukan manajemen dalam rangka efisiensi sehingga nilai perusahaan meningkat (Siregar \& Utama, 2008).

$\mathrm{H}_{\mathrm{a}}$ : discretionary accruals sebagai alat manajemen laba berpengaruh positif dan signifikan terhadap nilai perusahaan yang terdaftar di Bursa Efek Indonesia

\section{Metodologi Penelitian}

Populasi penelitian ini adalah perusahaan manufaktur yang terdaftar di Bursa Efek Indonesia yang menerbitkan laporan keuangan tahun 2013 - 2015. Sedangkan sampel dalam penelitian ini menggunakan metode purposive sampling dengan kriteria sebagai berikut:
(1) Perusahaan manufaktur yang terdaftar di dalam Bursa Efek Indonesia periode 2013 2015. (2) Perusahaan yang mempublikasikan laporan keuangan secara lengkap untuk periode 31 Desember 2013 - 2015 di dalam Bursa Efek Indonesia. (3) Perusahaan yang mengadopsi IFRS PSAK No. 16 (Revisi 2007) selama periode penelitian yaitu tahun 2013-2015. (4) Perusahaan yang terdaftar di Bursa Efek Indonesia yang menyajikan laporan keuangannya dalam bentuk rupiah.

Sumber data penelitian ini adalah data sekunder berupa laporan keuangan tahunan perusahaan manufaktur yang listing di Bursa Efek Indonesia melalui website BEI (www.idx.co.id). Teknik pengumpulan data adalah penelitian arsip (archival research).

Tabel 1. Sampel Penelitian

\begin{tabular}{llc}
\hline Keterangan & $\begin{array}{l}\text { Jumlah } \\
\text { sampel }\end{array}$ & \\
& Penelitian & \\
& & \\
\hline Jumlah Perusahaan yang & & \\
mengadopsi PSAK 16 (Revisi & 36 & \\
2012) berturut-turut 2013-2015 & & \\
Dikurangi & & \\
Laporan keuangan yang tidak \\
memiliki kelengkapan data \\
$\begin{array}{l}\text { periode 2013-2015 } \\
\text { Jumlah Sampel Penelitian }\end{array}$
\end{tabular}

Berdasarkan tabel 1, dapat dijelaskan bahwa perusahaan yang mengadopsi PSAK 16 (Revisi 2007) berjumlah 36 (100\%) perusahaan 
manufaktur periode 2013 - 2015, dari jumlah sampel penelitian diketahui 3 (8.3\%) perusahaan tidak memiliki kelengkapan data untuk periode 2013-2015 sehingga total keseluruhan sampel adalah 33 (91.7\%) perusahaan yang dapat dijadikan sampel penelitian.

\section{Teknik Analisis Data}

Dalam menganalisis data digunakan statistik inferens (statistik induktif). Untuk mengetahui tingkat signifikansi korelasi antara variabel independen (x) dan variabel independen (y), maka diperlukan model statistik untuk menguji hipotesis yang ditetapkan. Oleh karena itu hipotesis penelitian yang dirumuskan menunjukkan pada penelitian korelatif, maka teknik yang digunakan dalam menganalisis tingkat signifikansi untuk variabel independen terhadap dependen adalah model regresi linear berganda (multiple regression analysis).

$\mathrm{DAC}=\left(\mathrm{TAC}_{\mathrm{TA}} \mathrm{At}_{\mathrm{it}-1}\right)-\left(\alpha_{1}\left(1 / \mathrm{TA}_{\mathrm{it}-1}\right)+\right.$ $\beta_{1}\left(\left(\Delta \mathrm{REV}_{\mathrm{it}}-\Delta \mathrm{REC}_{\mathrm{it}}\right) / \mathrm{TA}_{\mathrm{it}-1}\right)+\beta_{2}\left(\mathrm{PPE}_{\mathrm{it}} / \mathrm{TA}_{\mathrm{it}-1}\right)+$ $\beta_{3}\left(\Delta \mathrm{REV} / \mathrm{TA}_{\mathrm{it}-1}\right)+\mathrm{e}$

Tobin's $\mathrm{Q}=\frac{M V E_{i t}+B V A_{i t}-B V E_{i t}}{T A_{i t}}$

Tobin's $\mathrm{Q}=\beta_{1} \mathrm{ROE}+\beta_{2} \mathrm{LEV}+\beta_{3}$ SIZE $+\mathrm{e}$

Tobin's $\mathrm{Q}=\beta_{0}+\beta_{1} \mathrm{DAC}+\beta_{2} \mathrm{ROE}+\beta_{3} \mathrm{LEV}+$ $\beta_{4} \mathrm{SIZE}+\mathrm{e}$

Dimana: DAC = discretionary accruals; Tobin's $\mathrm{Q}=$ nilai perusahaan; $\mathrm{ROE}=$ return on equity; $\mathrm{LEV}=$ rasio leverage yaitu total hutang dibagi total equity; Size = ukuran perusahaan, diproxi dengan total penjualan.

Tabel 2. Statistik Deskriptif

\begin{tabular}{|c|c|c|c|c|c|}
\hline & $\mathrm{N}$ & $\begin{array}{l}\text { Minimu } \\
\mathrm{m}\end{array}$ & $\begin{array}{l}\text { Maximu } \\
\mathrm{m}\end{array}$ & $\begin{array}{l}\text { Mea } \\
\mathrm{n}\end{array}$ & $\begin{array}{l}\text { Std. } \\
\text { Deviatio } \\
\text { n }\end{array}$ \\
\hline Tobin's & 3 & 0.40 & 15.57 & 1.49 & 1.93 \\
\hline Q & 3 & 0.0027 & 25.61 & 6 & 5.16 \\
\hline EM & 3 & 0.02 & 0.035 & 3.88 & 0.12 \\
\hline EIVI & 3 & 0.05 & 4.25 & 0.14 & 1.40 \\
\hline ROE & 3 & 5.59 & 7.33 & 1.35 & 0.49 \\
\hline LEV & $\begin{array}{l}3 \\
3\end{array}$ & & & 6.30 & \\
\hline SIZE & $\begin{array}{l}3 \\
3 \\
3\end{array}$ & & & & \\
\hline
\end{tabular}

Hasil pengujian statistik deskriptif pada tabel 2, diperoleh untuk variabel Tobin,s $Q$, nilai terendah 0.40 , nilai tertinggi 15.57 , nilai mean 1.496 dan standar deviasi 1.93. Variabel earning management diperoleh nilai terendah 0.0027, nilai tertinggi 25.61, nilai mean 3.88 dengan standar deviasi 5.16. Nilai terendah untuk variable ROE adalah 0.02 , nilai tertinggi 0.035 dan mean 0.14 , standar deviasi 0.12 . Variabel leverage yaitu nilai terendah 0.05 , nilai tertinggi 4.25 dan mean 1.35 dengan standar deviasi 1.40. Disamping itu, untuk variabel ukuran perusahaan dimana nilai terendah yaitu 5.59 dan tertinggi 7.33, mean 6.30 dengan standar deviasi 0.49 . 


\section{Hasil Penelitian dan Pembahasan}

Tobin's $\mathrm{Q}=\beta_{0}+\beta_{1} \mathrm{ROE}+\beta_{2} \mathrm{LEV}+\beta_{3} \mathrm{SIZE}+\mathrm{e}$

Tobin's $\mathrm{Q}=\beta_{0}+\beta_{1} \mathrm{DAC}+\beta_{2} \mathrm{ROE}+\beta_{3} \mathrm{LEV}+$ $\beta_{4} \mathrm{SIZE}+\mathrm{e}$

Tabel 3. Hasil Pengujian Hipotesis

\begin{tabular}{lllllll}
\hline Var. & \multicolumn{2}{l}{ Model 3 } & \multicolumn{5}{l}{ Model 4 } \\
\cline { 2 - 7 } & Koef. & $\mathbf{t}$ & Sig. & Koef. & $\mathbf{t}$ & Sig. \\
\hline Const. & 2.441 & & & 0.742 & & \\
EM & & & & - & 1.912 & 0.027 \\
ROE & 0.001 & - & 0.066 & 0.653 & 0.961 & 0.060 \\
LEV & - & 2.432 & & 0.045 & 0.102 & 0.121 \\
Size & 1.763 & 1.435 & 0.021 & 0.001 & 0.247 & 0.018 \\
& 4.561 & 0.345 & & 3.012 & & \\
N & & 33 & & & 33 & \\
F & & 5.103 & & & 4.224 & \\
Sig. F & & 0.041 & & & 0.026 & \\
Adj. & & 0.12 & & & 0.19 & \\
R $^{2}$ & & & & & &
\end{tabular}

\section{Signifikansi 5\%}

DAC $=$ discretionary accruals; Tobin's $\mathrm{Q}=$ nilai perusahaan; $\mathrm{ROE}=$ return on equity $; \mathrm{LEV}=$ rasio leverage yaitu total hutang dibagi total equity; Size = ukuran perusahaan, diproxi dengan total penjualan

Berdasarkan tabel 4 terlihat bahwa nilai $\mathrm{R}$ Square pada model 3 diperoleh sebesar 0,12. Hal ini berarti sebesar 12\% Tobin's Q dapat diprediksi dari variabel ROE, leverage dan ukuran perusahaan. Sedangkan pada model 4 diperoleh nilai $\mathrm{R}$ Square 0.19 , bearti $19 \%$ Tobin,s Q dapat diprediksi oleh manajemen laba dan dikontrol langsung oleh ukuran perusahaan. Dari tabel diatas, nilai $\mathrm{F}$ hitung dari model 3 adalah 5,103 dengan nilai probabilitas sebesar 0,041, yang lebih kecil dari 0,05. Model 4 adalah 4.226 dengan nilai probabilitas sebesar 0,026, yang lebih kecil dari 0,05 . Hal ini berarti bahwa kedua model regresi dapat digunakan dalam menjelaskan hubungan antar variabel.

Hasil pengujian hipotesis yaitu pengaruh manajemen laba terhadap nilai perusahaan pada model 4 menunjukkan nilai $\mathrm{t}$ sebesar 1.912 dengan nilai signifikansi $0.027<0.05$. dapat disimpulkan bahwa manajemen laba memiliki pengaruh negatif dan signifikan terhadap nilai perusahaan Tobin's Q. Disamping itu, untuk pengujian variabel kontrol ROE dan Leverage tidak berpengaruh terhadap nilai perusahaan dengan masing- masing tingkat signifikansi pada model 3 yaitu 0.066 dan 0.134 dan pada model 4 yaitu 0.060 dan 0.121 variabel ukuran perusahaan memiliki pengaruh positif dan siginifikan terhadap nilai perusahaan dengan nilai signifikansi 0.021 (model 3) dan 0.018 (model 4) lebih kecil dari 0.05.

PSAK No. 16 (2007) Aset Tetap yang diadopsi dari IAS 16 (2003) dan menggantikan PSAK No. 16 (1994) Aset Tetap dan Aset Lainnya, efektif pada 1 Januari 2012. Perubahan signifikan dalam revisi PSAK ini adalah perusahaan dapat memilih model revaluasi untuk mengukur aset tetap. Sebelum revisi, perusahaan 
diwajibkan untuk menggunakan model biaya saja. Namun, semua perusahaan dalam sampel memilih untuk menggunakan model biaya daripada beralih ke model revaluasi ketika PSAK No. 16 (2007) pertama kali dilaksanakan. Oleh karena itu, perubahan dalam standar ini tidak menghasilkan perubahan yang signifikan dalam kebijakan akuntansi dan akrual diskresioner manajemen laba.

Dari hasil pengujian hipotesis diperoleh bahwa manajemen laba berpengaruh negatif terhadap nilai perusahaan. Hasil temuan ini mendukung penelitian Zhang et al (2007), dan Huang et al (2009). Pengaruh negatif tersebut menandakkan bahwa tindakan manajemen laba akan menurunkan nilai perusahaan. Hal ini dapat dijelaskan bahwa manajemen laba melalui akrual diskresioner mudah dideteksi serta mengandung unsur subyektifitas dan manipulasi yang tinggi. Jadi, ketika akrual dinilai investor sebagai tindakan manipulasi manajemen maka investor tidak mempercayai apa yang telah dilakukan oleh manajemen, kondisi inilah yang menyebabkan nilai perusahaan menurun (Huang et al, 2009).

Perkembangan akuntansi dalam konteks sosial dan praktik budaya yang kian beragam semakin mengukuhkan eksistensi paradigma kualitatif. Kemampuannya menghasilkan produk analisis yang mendalam selaras dengan settingnya. Beberapa metode penelitian berbasis kualitatif ini seperti; analisis wacana, studi kasus, semiotik dan etnografi kini mulai dilirik para ilmuwan dan peneliti akuntansi. Menyadari akan pentingnya manfaat multiparadigma dalam riset akuntansi maka peneliti mencoba menyelami metode pendekatan yang berbeda dengan pendekatan-pendekatan antropologi yaitu; pendekatan enterpretive dengan tujuan untuk mendapatkan gambaran khusus instisari kebudayaan yang diteliti.

Studi ini menggunakan pendekatan kualitatif atau non-positivistik dengan pendekatan deskriptif. Adapun cara yang dilakukan penulis dalam pembhasan ini menggunakan perubahan standar yang berlaku, yang dari US GAAP ke penerapan IFRS, dengan berlakunya IFRS ini metode pencatatan yang berlaku juga berubah dari metode cash basis di ijinkan, berubah menjadi hanya metode accrual basis yang diterapkan.

\section{Hasil dan pembahasan}

Penelitian ini bertujuan untuk memberikan bukti empiris dan mengetahui gambaran hubungan adopsi IFRS PSAK 16 (Revisi 2007) dengan discretionary accruals sebaga alat manajemen laba dan pengaruhnya terhadap nilai perusahaan. Dari hasil pengujian hipotesis diperoleh bahwa manajemen laba berpengaruh negatif terhadap nilai perusahaan. Pengaruh negatif tersebut menandakkan bahwa tindakan manajemen laba akan menurunkan nilai perusahaan. Hal ini dapat dijelaskan bahwa manajemen laba melalui akrual diskresioner mudah dideteksi serta mengandung unsur subyektifitas dan manipulasi 
yang tinggi. Jadi, ketika akrual dinilai investor sebagai tindakan manipulasi manajemen maka investor tidak mempercayai apa yang telah dilakukan oleh manajemen, kondisi inilah yang menyebabkan nilai perusahaan Huang et al (2009).

Beberapa keterbatasan dalam penelitian ini perlu dikemukakan agar interprestasi hasil penelitian dilakukan secara hati-hati dengan mempertimbangkan segala keterbatasan yang ada. Selain itu, keterbatasan penelitian berguna bagi pengembangan penelitian sejenis dimasa depan. Adapun keterbatasan dalam penelitian ini adalah masih sedikitnya perusahaan yang memilih revaluasi aset tetap. Disarankan pada penelitian selanjutnya untuk menguji di periode berbeda atau jenis perusahaan yang berbeda.

\section{DAFTAR PUSTAKA}

Azouzi, Mohamed Ali \& Anis Jarboul. 2012.

The Evidence of Management motivation to revalue property plant and Equipment in Tunisia, Journal of Accounting and Taxation, Vol. 4(2).

Brown, P., Izan, H.Y. \& Loh, A. L. 1992. Fixed asset revaluations and managerial incentives. Abacus. Vol. 28 No. 1, pp. 3657.

Cai, L., A. R. Rahman, \& S. M. Courtenay. 2008. The Effect of IFRS and Its Enforcement on Earnings Management : An International Comparison. Social
Science Research Network Electronic Paper Collection.

Christensen, H. B. \& Nikolaev, V. 2013. Does fair value accounting for non-financial assets pass the market test? Review of Accounting Studies, Vol. 18 No.3, pp. 734-775.

Cotter, J. \& Zimmer, I. 1995. Asset revaluations and assessment of borrowing capacity. Abacus. Vol. 31 No 2, pp. 136-151.

Dewan Standar Akuntansi Indonesia. 2012. Standar Akuntansi Keuangan Per 1 Juni 2012. Jakarta : Ikatan Akuntan Indonesia.

Hu, Fang, Percy, Majella, dan Yao, Daifei. 2015. Asset revaluations and earnings management: Evidence from Australian companies. Corporate Ownership and Control. 13(1), pp. 930-939.

Huang, P., Zhang, Y., Deis, Donald R., \& Moffitt, J. S. 2009. Do artificial income smoothing and real income smoothing contribute to firm value equivalenty? Journal of Banking \& Finance. 33, 224233.

Jensen, M. \& W. Meckling. 1976. Theory of the Firm : Managerial Behavior, Agency Cost dan Ownership Structure. Journal of Financial Economics (3) : 305-360.

Laili, Y. R. 2008. Pengaruh Penerapan Konvergensi IFRS terhadap Penilaian Aset dengan Menggunakan Konsep Fair Value. Jurnal Ekonomi dan Akuntansi , 124 
Lambert, R. A. 2001. Contracting Theory and Accounting. Journal of Accounting and Economics (32) : 3-87.

Ross, S. A., Westerfield, R. W., \& Jaffe, J. 2010. Corporate Finance, 9th ed. McGraw Hill.

Schipper, K. 1989. Earnings Management. Accounting Horizons 3, 91-106

Scott, William R. 2009. Financial Accounting Theory. 5th edition. Prentice Hall.

Scott, W. R. 2012. Financial Accounting Theory. Sixth Edition. Pearson Prentice Hall. Toronto

Shoorvarzy, M. R., \& Tuzandehjani, M. 2011. The Impact of Accounting Standard Setting on Earning Response. World Applied Sciences Journal , 1369-1373.

Siregar, S. V., \& Y. S. Bachtiar. 2003. Hubungan Antara Manajemen Laba dengan Tingkat Pengungkapan Sosial. Simposium Nasional Akuntansi VI.

Wang, Zhemin, 2006. Upward Revaluation of Fixed Assets, Journal of Business and Economics Research Vol. 4, No. 1

Wondabio, Ludovicus Sensi. 2011. Konvergensi IFRS dan Pemahaman PSAK terkini, Pelatihan Dampak Penerapan PSAK Terbaru Berbasis IFRS terhadap Dunia Pendidikan dan Industri, Padang.

Whittred, G. \& Chan, Y. K. 1992. "Asset revaluations and the mitigation of underinvestment". Abacus, Vol. 28 No. 1, pp. 58-74.
Yip, W. H., \& Nguyen, H. 2012. Exchange rate exposure and the use of foreign currency derivatives in the Australian resources sector. Journal of Multinational Financial Management, 22,151-167.

Watts, R. L. \& J. L. Zimmerman. 1990. Positive Accounting Theory: A Ten Year Perspective. The Accounting Review 65 (1) : 131-156.

Zang, Amy Y. (2007). Evidence on the Tradeoff between Real Manipulation and Accrual Manipulation. The Accounting Review, Vol. 87. American Accounting Association.

Zhang, Haiwen. 2009. Effect of Derivative Accounting Rules on Corporate RiskManagement Behavior. Journal of Accounting and Economics, 47, 244-264 